\title{
Integrated Goat Fish Farming as Source of Low Cost Nutrition Security for Small Farmers
}

\author{
Bibha Chetia Borah ${ }^{1 *}$, Sonmoina Bhuyan ${ }^{2}$ and Biswajyoti Bordoloi ${ }^{3}$ \\ ${ }^{1}$ Principal Scientist and In-charge, Fisheries Research Centre, Assam Agricultural \\ University, Jorhat, Assam, India \\ ${ }^{2}$ Subject Matter Specialist, KVK, Lakhimpur, AAU, Assam, India \\ ${ }^{3}$ Junior Scientist, FRC, AAU, Jorhat, Assam, India \\ *Corresponding Author: Bibha Chetia Borah, Principal Scientist and In-charge, \\ Fisheries Research Centre, Assam Agricultural University, Jorhat, Assam, India.
}

Received: November 27, 2020

Published: January 21, 2021

(C) All rights are reserved by Bibha Chetia

Borah., et al.

DOI: $10.31080 /$ ASNH.2020.05.0813

\begin{abstract}
As per the $20^{\text {th }}$ livestock census (2019), the population of goat in India is 148.88 million, which is $10.14 \%$ higher than the same in the 19th livestock Census, 2012 and around 27.8\% of the total livestock population of the country. The increase in livestock population is always associated with the problem of waste disposal and its possible impact on the environment. Integration of fish farming with livestock husbandry is a viable option, where the livestock waste is recycled for production of fish. The present study encompasses integrated farming of goat and fish by recycling goat manure, a rich source of $\mathrm{N}(2.7 \%), \mathrm{P}(1.7 \%)$ and $\mathrm{K}(2.9 \%)$ and protein (17.3\%), for enhancing fish production in pond. The average range of production of goat dung was $106.2 \mathrm{gm}-176.4 \mathrm{gm} / \mathrm{goat} / \mathrm{night}$ for animal weighing 10.5 - $17.5 \mathrm{~kg}$ under open grazing system. It was found that application of goat dung @ 10,000 kg/Ha/year in split doses is the most viable proposition. Calculated per Ha production of fish @ 3879.4 kg (T2), 3430.8 kg (T3), 3358.9 kg (T1) and $2061.8 \mathrm{~kg}(\mathrm{C})$ indicated the comparative efficiency of goat dung application for small scale sustainable fish farming with low external input.
\end{abstract}

Keywords: Livestock Population; Waste Disposal; Integration; Goat Manure Recycling; Sustainable; Small Scale Fish Farming

\section{Introduction}

Livestock supports the livelihoods and food security of a large section of people of rural India. According to the recently concluded $20^{\text {th }}$ Livestock Census of India, 2019, the total livestock population of the country is 535.78 million, which is $4.6 \%$ higher than the livestock population recorded during the $19^{\text {th }}$ livestock Census, 2012. This enhancement in livestock population is primarily due to the increase in population of small animals like sheep and goat in the country (Figure 1). This indicated the increasing popularity of small animals among the farmers of the country as a means of livelihood and sustenance. According to recent Census Report (2019) the number of goats is 148.88 million, which is around $27.80 \%$ of the total livestock population of the country, securing the position of second largest group of livestock in the country next to cattle in terms of population and $10.14 \%$ higher than the goat population recorded in previous livestock census, 2012 (135.17 million).

Among different livestock, farming of goat is very popular among the small and marginal farmers as an assured remunerative activity with low input and space. In the North East Region of the country, comprised of eight land locked states viz. Arunachal Pradesh, Assam, Manipur, Meghalaya, Mizoram, Nagaland, Tripura and Sikkim, situated in the eastern Himalayan Region between longitude $21^{\circ} 57^{\prime}$ to $29^{\circ} 30^{\prime} \mathrm{N}$ and latitude $84^{\circ}-46^{\prime}$ to $97^{\circ}-30^{\prime} \mathrm{E}$, with a 


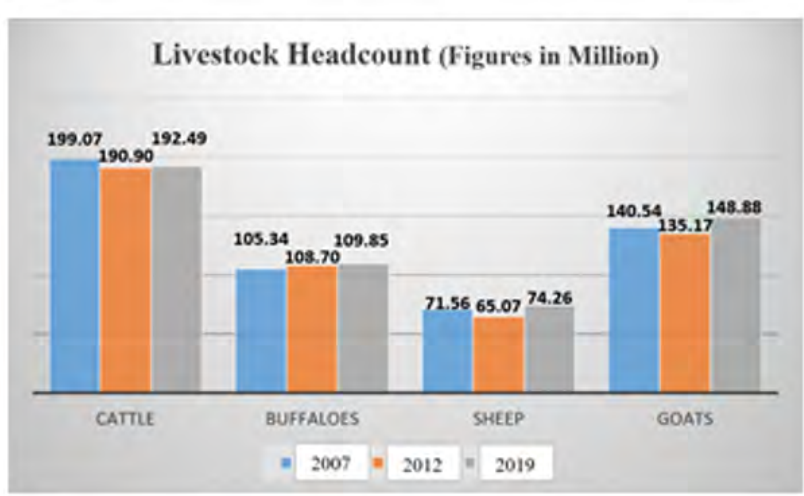

Figure 1: Trend of livestock population in India.

total population of 457,72,188 (around 4\% of the country's total, Census 2011) comprising of around 220 ethnic communities with $90-100 \%$ non vegetarian food habit, goat raising is a popular activity for securing livelihood and family nutrition. Particularly in the state of Assam, the goat farming is a common economic activity as a part of the traditional homestead family farming system. The total goat population in the NE Region of India as a whole was recorded to be $54,08,245$, out of which around $79.8 \%(43,15,173$ nos) was recorded in the state of Assam. These statistics indicated the importance of goat keeping in the state's economy and depict its popularity as a means of livelihood and nutritional security particularly for the small and marginal farmers of the rural areas. Assam Hill goat, the local variety of goat is predominant among the small farmers of the state, along with some high yielding varieties like Beetal, Sirohi etc. and cross among them.

The increase in livestock population is always associated with the problem of waste disposal as well as its possible impact on the environment including green house gas emission [1]. This calls for systematic study on utilization of the livestock manure in production of other commodities in such a way so as to minimise the impact on environment while assuring maximum production of the desired commodities. Fish ponds may serve as a waste treatment system for the animal manure which otherwise cause pollution to the environment [2,3] and even contribute to carbon sequestration [4]. In India several technologies for integration of fish farming with different livestock (cattle, pig) and birds (poultry and duck) farming has been developed (where the manure from livestock and birds is recycled for production of fish) and advocated as a viable option for efficient utilization of available bio resources and production of food with low external input, that had been popularised with suitable location specific modifications, improvisations, and intensification in different states of the country [5-10]. Goat dung is considered to be good manure for agricultural crops and is known to be a rich source of $\mathrm{N}(2.7 \%), \mathrm{P}(1.7 \%)$ and $\mathrm{K}(2.9 \%)$ and protein $(17.3 \%)$, much higher than that of manure from cattle, pig, rabbit, poultry and duck $[11,12]$. However, its probable use in fish farming for enhancing pond productivity has not been studied in detail except for a few studies conducted in different parts of the world [13-15].

In view of the above, the present study was undertaken on possible utilization of goat dung in fish culture in Assam with a hypothesis that goat dung as an easily available input with high NPK content will be a suitable option for small farmers in enhancing fish production in the state of Assam with low external input. The work was carried out as a part of a research project under the Non-Project Faculty Research Component of Assam Agricultural University during 2013-2019 at Fisheries Research Centre, AAU, Jorhat, Assam, India (Figure 2).

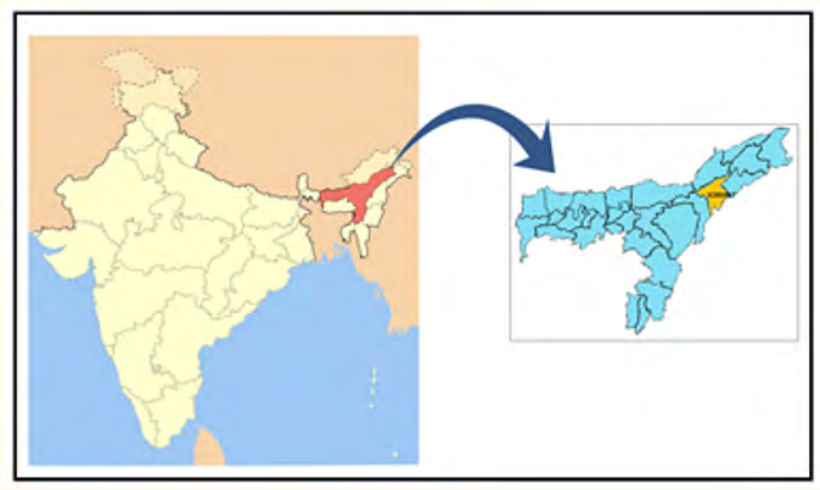

Figure 2: Map of India showing the location of study.

\section{Materials and Methods}

The experiments were conducted in three phases as detailed below: 
- Preliminary study on time/days required for decomposition of fresh goat dung in water was carried out by using 5 plastic tubs (capacity 20 liters) filled with pond water and putting fresh sample of goat dung @1 kg to each tub. Weekly observation on decomposition of goat dung was carried out till 45 days. For comparison of decomposition process another set of treatments was conducted by using same quantity of goat dung, air dried and macerated and put in water by using similar plastic tubs. Sampling was done as per standard procedure [16].

- Quantification of goat manure produced per animal (under open grazing system) per night was done by keeping the animals separately (live weight of each goat recorded) over night, collecting and taking weight of the dung in the morning to assess the quantity produced per kg live weight of the goat as per standard method of total fecal output collection [17] and calculate the number of animals required for fertilizing unit water area. The study was done continuously for 10 consecutive days with goats (Beetal x Assam Hill goat) of different size groups.

- Study on impact of application of different doses of goat dung on water quality parameters was conducted by using 5 nos. of cement cisterns with uniform size (Length $3.0 \mathrm{~m}$, breadth $2.0 \mathrm{~m}$ and height $0.75 \mathrm{~m}$ ). Four treatments with goat manure with 3 replications of each treatment were conducted with split up application doses as shown in the Table- 1. One control was kept without manure for comparison. Initial and periodic water quality parameters assessment was done at 15 days interval [18].

- Growth and production of different carps in earthen ponds treated with different doses of goat manure was studied by using 4 nos earthen ponds with area 500 sqm/pond (Table 2), prepared and stocked by following six species composite carp culture technology (Annon, 1997) @ Rohu (Labeo rohita)-15\%, Catla (Catla catla)-15\%, Mrigal (Chirrhinus mrigala)-20\%, Silver carp (Hypohthalmichthys molitrix)-20\%, Grass carp (Ctenopharyngodon idella)- 10\%, and Common carp (Cyprinus carpio)-20\%@ 8,800 nos./ha.

Initial and periodic water quality parameters assessment was done at 15 days interval (as per APHA 1989). No supplementary feeding was done in any of the treatments. Harvesting was done on

\begin{tabular}{|l|c|c|c|c|}
\hline \multirow{2}{*}{ Treatments } & \multirow{2}{*}{$\begin{array}{c}\text { Rate of } \\
\text { Goat } \\
\text { manure } \\
\text { Kg/ha/ } \\
\text { year }\end{array}$} & $\begin{array}{c}\text { quantity of } \\
\text { goat manure } \\
\text { applied } \\
\text { Kg/cistern/ } \\
\text { year }\end{array}$ & $\begin{array}{c}\text { Dose applied/ } \\
\text { cistern (kg) }\end{array}$ \\
\cline { 4 - 5 } & $\begin{array}{c}\text { Initial } \\
\text { dose } \\
\mathbf{( 1 / 3 r d )}\end{array}$ & $\begin{array}{c}\text { Monthly } \\
\text { install- } \\
\text { ment } \\
\text { (10) }\end{array}$ \\
\hline $\mathrm{T}_{1}$ & 5,000 & 3.0 & 1.0 & 0.200 \\
\hline $\mathrm{T}_{2}$ & 7,500 & 4.5 & 1.5 & 0.300 \\
\hline $\mathrm{T}_{3}$ & 10,000 & 6.0 & 2.0 & 0.400 \\
\hline $\mathrm{T}_{4}$ & 15,000 & 9.0 & 3.0 & 0.600 \\
\hline Control & $\begin{array}{c}\text { No } \\
\text { manure }\end{array}$ & 0 & 0 & 0 \\
\hline
\end{tabular}

Table 1: Treatment with goat manure in cement cisterns (volume $3.0 \mathrm{~m}$ X $2.0 \mathrm{~m}$ X $0.75 \mathrm{~m})$.

\begin{tabular}{|l|c|c|c|c|}
\hline & & Rate of & $\begin{array}{c}\text { Rate of } \\
\text { application } \\
\text { Treatments }\end{array}$ & \multicolumn{2}{|c|}{$\begin{array}{c}\text { Dose of } \\
\text { application } \\
\text { (kg/500sqm) }\end{array}$} \\
\cline { 4 - 6 } & $\begin{array}{c}\text { Kgplication } \\
\text { Kg/ha/year } \\
\text { year }\end{array}$ & $\begin{array}{c}\text { Monthly } \\
\text { Initial } \\
\left(\mathbf{1} / \mathbf{3}^{\text {rd }} \mathbf{)}\right.\end{array}$ & $\begin{array}{c}\text { (10 } \\
\text { install- } \\
\text { ments) }\end{array}$ \\
\hline $\mathrm{T}_{1}$ & $7,500.0$ & 375.0 & 125.0 & 25.0 \\
\hline $\mathrm{T}_{2}$ & $10,000.0$ & 500.0 & 167.0 & 33.3 \\
\hline $\mathrm{T}_{3}$ & $15,000.0$ & 750.0 & 250.0 & 50.0 \\
\hline Control & No manure & - & - & - \\
\hline
\end{tabular}

Table 2: Treatment in earthen ponds (500sqm) with goat manure.

$11^{\text {th }}$ month of rearing by complete dewatering and growth of different fish species was recorded in different treatments and compared. Final yield of fish was calculated $(\mathrm{kg} / \mathrm{ha})$ and compared to find out the best treatment.

\section{Results and Discussion}

The trials on decomposition of fresh goat dung pellet under submerged condition in water revealed that the decomposition process of goat dung was very slow. There was very minimum change in the texture, shape and size of the goat dung pellets up to 35-40 days. After 30-38 days, the water became turbid and blackish color indicating slow diffusion of nutrients from the pellets into the water. Complete decomposition of the pellets could not be achieved up to 
45 days of observation. Similar findings were recorded by Grimsby., et al. [19] who observed that goat manure having high Total Solid content (50\%) maintained their shape and floated in water till 50 days during anaerobic stirred reactor trial. Ugwuoke., et al. [19], reported slow anaerobic digestion of goat dung due to inadequate lignocelluloses breakdown and slow activities of anaerobic bacteria during initial days when used for biogas production. Higher percentage of Total Solid (50\%) and Lignin (21\%) in goat dung in comparison to some other livestock manure like cow dung and pig droppings might be the reason for slow decomposition [19]. In contrast, the air dried and grinded goat manure was mixed with water readily and the decomposed after 7-8 days of application. This was in agreement of Grimsby., et al. [19], who stated that maceration of goat droppings was needed to reduce the particle size and enhance anaerobic digestion. These observations indicated that goat dung in macerated form is more suitable for application in fish culture ponds in comparison to the fresh pellet form, for obtaining prompt desired impact on water quality and productivity.

The study on quantification of goat dung produced by the animals (Beetal x Assam Hill goat) of known weight revealed substantial variation without any distinct trend (Table 3). The wide fluctuation in weight of goat dung produced per night by the same animal may be due to the feeding rate/frequency and type of feed taken during grazing by the day. Similar kind of variation in goat dung produced per animal was also reported by Grimsby., et al. [19]. The average range of production of goat dung was recorded at 106.2 gm - 176.4gm/goat/night for animal weighing from $10.5 \mathrm{~kg}-17.5$ kg. Earlier Grimsby., et al. [19], recorded 166 gm TS/goat/day to $378 \mathrm{gm}$ TS/goat/day for different age group of Red Sokota goats in
Nigeria grazed under different situations. This indicated that manure produced by goat may vary depending on species, age, size and feed, feeding intensity and feeding pattern.

The study of the impact of goat dung application on water quality parameter in cement cisterns indicated highest turbidity and $\mathrm{pH}$ in $T_{4}$ indicating the impact of goat dung at higher dose on water quality. Significant enhancement in growth of plankton population in the treated cisterns was recorded in comparison to the untreated one which was in agreement with Megerssa., et al. [20], who found abundant growth of plankton in goat manure treated pond in comparison to other livestock manure. The plankton population was recorded to be in the most desirable range [21] in treatment $T_{3}$ indicating the efficacy of the dose @ 10,000 kg goat dung/hectare/ year in enhancing primary productivity (Table 4 ). This was supported by the optimum BOD and COD range [21] as well as other water quality parameters recorded in the trial as shown in the table 4. Earlier, Megerssa., et al. [20] reported higher plankton production in goat manure treated ponds that had positive impact on growth of filter feeder fish species like Tilapia and Carps without any supplementary feeding.

The growth performance and total yield of fish in earthen ponds with different dose of goat manure without any supplementary feeding (Table 5) indicated that significantly higher production could be achieved with goat manure treated ponds in comparison to the control. This finding was in agreement with earlier study by Megerssa., et al. 2016. Highest production was achieved in pond with goat dung application @ 10,000 kg/ha/year (T2) (significant at 0.05 level), followed by 15,000 kg/ha (T3), 7,500 kg/ha (T1) and

\begin{tabular}{|l|c|c|c|c|c|c|c|c|c|c|c|}
\hline \multicolumn{10}{|c|}{ Goat manure produced (gm/animal/night) } \\
\hline Wt. of goat (kg) & Day 1 & Day 2 & Day 3 & Day 4 & Day 5 & Day 6 & Day 7 & Day 8 & Day 9 & Day 10 & Average \\
\hline 12.0 & 145 & 90 & 96 & 84 & 176 & 144 & 96 & 90 & 125 & 95 & 114.1 \\
\hline 17.0 & 160 & 130 & 166 & 110 & 274 & 197 & 166 & 130 & 145 & 286 & 176.4 \\
\hline 15.0 & 168 & 141 & 160 & 145 & 140 & 163 & 210 & 94 & 138 & 121 & 148.0 \\
\hline 11.0 & 98 & 110 & 65 & 125 & 130 & 154 & 110 & 90 & 210 & 151 & 124.3 \\
\hline 10.5 & 75 & 85 & 31 & 86 & 90 & 130 & 163 & 95 & 167 & 140 & 106.2 \\
\hline 12.0 & 148 & 151 & 90 & 198 & 150 & 105 & 200 & 176 & 96 & 145 & 145.9 \\
\hline 17.5 & 178 & 168 & 110 & 248 & 286 & 87 & 143 & 160 & 130 & 159 & 166.9 \\
\hline
\end{tabular}

Table 3: Quantification of Goat (Beetal XAssam Hill goat.) manure. 


\begin{tabular}{|c|c|c|c|c|c|}
\hline Parameters & $\mathbf{T}_{1}$ & $\mathbf{T}_{2}$ & $\mathbf{T}_{3}$ & $\mathrm{~T}_{4}$ & Control \\
\hline DO (ppm) & $5.00-7.35$ & $5.75-8.10$ & $5.35-8.25$ & $3.25-6.90$ & $5.25-8.65$ \\
\hline Temperature $\left({ }^{\circ} \mathrm{C}\right)$ & $14^{\circ} \mathrm{C}-31^{\circ} \mathrm{C}$ & $15^{\circ} \mathrm{C}-31^{\circ} \mathrm{C}$ & $15^{\circ} \mathrm{C}-32^{\circ} \mathrm{C}$ & $16^{\circ} \mathrm{C}-32.5^{\circ} \mathrm{C}$ & $15^{\circ} \mathrm{C}-31^{\circ} \mathrm{o}$ \\
\hline Turbidity (ppm) & $17.5-19.0$ & $18.3-19.2$ & $18.5-23.3$ & $23.0-27.5$ & $12.0-13.0$ \\
\hline $\mathrm{pH}$ & $7.8-8.45$ & $7.7-8.55$ & $7.4-8.18$ & 8.1-8.8 & $6.6-7.2$ \\
\hline Conductivity $(\mathrm{mS} / \mathrm{cm})$ & 54- 154 & 68- 175 & $98-237$ & $122-278$ & $45-68$ \\
\hline $\mathrm{CO}_{2}(\mathrm{ppm})$ & $5.0-7.0$ & $5.5-7.3$ & $5.3-7.5$ & $6.7-8.3$ & $4.8-6.3$ \\
\hline COD (mg/L) & $16-24$ & $18-27$ & $22-28$ & $34-38$ & $14-25$ \\
\hline $\mathrm{BOD}(\mathrm{mg} / \mathrm{l})$ & $3.9-4.0$ & $4.3-5.1$ & $4.7-5.4$ & $5.3-6.0$ & $2.9-3.3$ \\
\hline $\begin{array}{l}\text { Plankton population } \\
\text { (nos/l) }\end{array}$ & $2100-3645$ & $2540-3510$ & $3745-4350$ & $4525-5380$ & $1937-2870$ \\
\hline Alkalinity (ppm) & $53.6-61.3$ & $69.3-76.0$ & $77.0-85.5$ & $89.0-94.5$ & $27.5-43.3$ \\
\hline
\end{tabular}

Table 4: Water quality parameters under different treatments.

control(C) in the descending order. Calculated per hectare production was $3879.4 \mathrm{~kg}$ (T2), $3430.8 \mathrm{~kg}$ (T3), $3358.9 \mathrm{~kg}$ (T1) and 2061.8 $\mathrm{kg}(\mathrm{C})$ respectively (Figure 3 ), which depicted the comparative efficiency of different doses of goat dung application. The inherent ecological bottleneck in the form of low range of ambient temperature $\left(<18^{\circ} \mathrm{C}\right)$ prevailed in the state during winter months (November- February) had a negative impact on the growth of fish during that period [22]. Similar findings were recorded in earlier studies on semi intensive composite culture in the state [23,24]. Species wise production data revealed that the highest production could be achieved in Silver carp, which might be due to abundance of phytoplankton growth, the major natural food for the species, due to goat manure application.

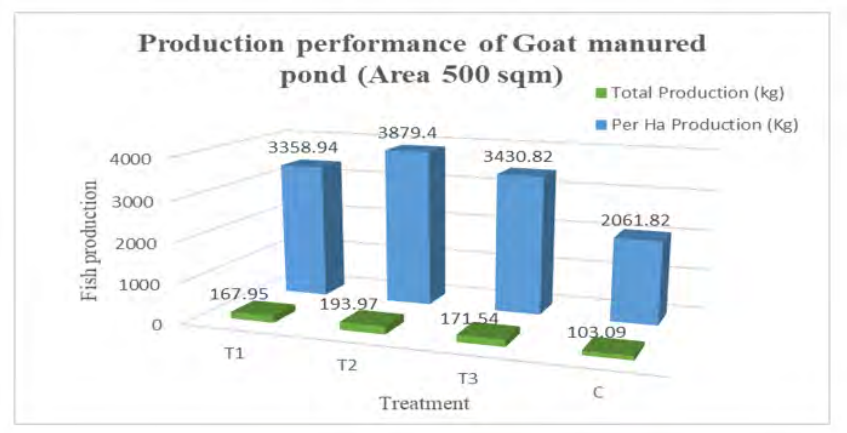

Figure 3: Production performance of Goat Manured Pond (Area 500sqm).
The number of animals required for fertilizing a $1,000 \mathrm{sqm}$ pond (as a small unit pond) and for 1 ha area was also calculated out to be 25-30 nos. and 250-300 nos. respectively on the basis of average amount of goat dung produced per animal of varying sizes. Earlier, Libunao (1990) reported that integration of 300 goats per ha is the most efficient proposition for production of Tilapia $(O$. niloticus) exhibiting highest yield. Although it was reported that growth performance of some fish species is better when fed with formulated feed than grown with goat dung only [14], yet application of goat manure in proper dose in fish pond may be an efficient proposition for resource poor farmers who have a herd of goats and small pond in their homestead as an efficient option for securing nutrition and livelihood with low external input cost in an environment friendly way.

The result of the study opens a new avenue for integrating goat farming with fish farming as an efficient farming system model for small and marginal fish farmers. Although further study on performance of different fish species combination and stocking density, fortification and application schedule are required, the results of the present study can be taken as a basis for formulating an efficient package of practice in due course.

\section{Acknowledgement}

The authors acknowledge their deep sense of gratitude to Dr. K.M. Bujarbaruah, former Vice Chancellor, Assam Agricultural University for his valuable suggestions and supports provided during 


\begin{tabular}{|c|c|c|c|c|c|c|c|c|c|c|c|c|c|c|c|c|}
\hline \multirow{2}{*}{$\begin{array}{c}\text { Species } \\
\text { and nos.** } \\
\text { Stocked/pond }\end{array}$} & \multicolumn{4}{|c|}{$\begin{array}{c}\text { Initial av. weight } \\
\text { (gm) }\end{array}$} & \multicolumn{4}{|c|}{$\begin{array}{c}\text { Final av. weight } \\
\text { (gm) }\end{array}$} & \multicolumn{4}{|c|}{ Production (gm)/pond } & \multicolumn{4}{|c|}{ Nos. recovered and \% of recovery* } \\
\hline & $\mathrm{T}_{1}$ & $\mathbf{T}_{2}$ & $\mathbf{T}_{3}$ & C & $T_{1}$ & $\mathbf{T}_{2}$ & $\mathbf{T}_{3}$ & $\mathrm{C}$ & $\mathrm{T}_{1}$ & $T_{2}$ & $\mathbf{T}_{3}$ & $\mathrm{C}$ & $T_{1}$ & $T_{2}$ & $\mathbf{T}_{3}$ & C \\
\hline \begin{tabular}{|l|} 
Rohu \\
$(66)$
\end{tabular} & 25 & 20 & 23 & 22 & 440 & 530 & 511 & 400 & 20680 & 26500 & 23506 & 17600 & $47(71.2)$ & $50(75.8)$ & 46 (69.7) & $44(66.7)$ \\
\hline $\begin{array}{l}\text { Mrigal } \\
(88)\end{array}$ & 20 & 18 & 18 & 22 & 430 & 465 & 433 & 320 & 27950 & 31620 & 28578 & 20800 & $65(73.9)$ & $68(77.3)$ & $66(75.0)$ & $65(73.9)$ \\
\hline $\begin{array}{l}\text { Common Carp } \\
(88)\end{array}$ & 45 & 40 & 40 & 45 & 445 & 520 & 480 & 326 & 28925 & 34840 & 29760 & 18256 & $65(73.9)$ & $67(76.1)$ & $62(70.5)$ & $56(63.6)$ \\
\hline
\end{tabular}

Table 5: Growth of fish in goat manure treated pond (Area 500sqm/pond, stocking @ 8,800 nos./ha)

Culture period: 10 months.

*Figures in parentheses indicate \% of recovery.

**Figures in parentheses indicate number stocked for each species.

this study and to Dr Apurba Kumar Chakraborty, former Director of Research, College of Veterinary Science, Assam Agricultural University, Khanapara, Assam, for the fund provided under the NPFR programme of the University. They are also thankful to all the workers of Fisheries Research Centre, Assam Agricultural University, Jorhat, Assam, for their whole hearted cooperation during the study and Ms. Akankshita Borah for her sincere help in preparation of this manuscript.

\section{Bibliography}

1. Goodland R and Anhang J. Pub. Livestock and Climate change. www.worldwatch.org. November-December. World Watch (2009): 10-19.

2. Edwards P., et al. Pub. ICLARM Studies and Reviews. 16 (1998): 53.

3. Schroeder GL. ICLARM Conference proceedings 4 (1980): 7386.

4. Boyd Claude E. "Aquaculture pond holds carbon". Global Aquaculture Advocate (2010): 23-24.

5. Sharma BK., et al. "Package of Practice for increasing production on fish cum livestock farming system". Aquaculture Extension Manual New Series, No. 5, CIFRI, Barrackpore (1985).
6. Anonymous. Package of practices for fish farming in Assam. Assam Agricultural University, Jorhat, Assam and Dept. of Fisheries, Govt of Assam (1997): 104.

7. Chetia Borah B., et al. "Integrated poultry-pig-fish farming". Journal of Inland Fisheries Society of India 30.1 (1998): 39-46.

8. Chetia Borah B., et al. "Techno-economic feasibility of cow manure recycling in fish pond". Indian Jr. Hill Farming 12 (1999): 1-7.

9. Chetia Borah B and Bhuyan S. "Sustainability of an integrated livestock-fish-crop farming system as a small scale enterprise". Pub. Aquaculture Asia Magazine, April-June. (2017): 18-20.

10. Chetia Borah B., et al. "Technical viability of incorporation of low cost Aquaponics in integrated chicken fish farming system". The Bioscan 10 (2017): 01-08.

11. Gaddie ER and Douglas DE. Pub. Earth worm for Ecology and profit, Vol.1 Scientific Earthworm farming. Bookworm publishing Company, Ontario California, USA (1975).

12. NACA. "Integrated fish farming in China". Publ. NACA Technical Manual-7 (1989). 
13. Libunao P Lyndia. "Goat/fish integrated farming in the Phillipines". Ambio. Science of Sustainable Development 19.8 (1999): 408-410.

14. Soko CK and Likongwe JS. "Effects of fertilization and feeding on the growth of Tilapia rendalli reared in concrete ponds". Aqua-Fish Technical Report 1 (2002): 29-31.

15. Megerssa E., et al. "Fish growth performance in ponds integrated with poultry farm and fertilized with goat manure: a case in Ethiopian Rift valley". International Journal of Fishery Science and Aquaculture 3.2 (2016): 040-045.

16. Peters J Combs., et al. "Recommended methods of manure analysis (A3769)". Pub. by Co-operative Extension Publishing (2003): 62.

17. Coates DB and Penning P. "Measuring animal performance". in: Mannetje, Lt., Jones, R.M. (Eds), Field and laboratory methods for Grassland and animal production research. Electronic Book published by www.cabi.org (2000): 353-386.

18. APHA. Standard methods for examination of water and waste water. 16 Ed. APHA, AWWA, WPCE, Washington DC (1989): 1014.

19. Grimsby LK., et al. "The prospect of Biogas among small holder dairy goat farmers in the Uluguru Mountains, Tanzania". African Journal of Food, Agriculture, Nutrition and Development 16.1 (2016): 10723-10737.

20. Ugwuoke EC., et al. "Production of Biogas from goat dung by anaerobic digestion". International Journal of Research in Advanced Engineering and Technology 2.5 (2016): 17-20.

21. Bhatnagar A and Devi Pooja. "Water quality guidelines for the management of pond fish culture". International Journal of Environmental Sciences 3.6 (2013): 1980-2009.

22. Chetia Borah B and Bania R. "An innovative approach to address inadequacy in environmental factors for development of aquaculture in Assam". Pub. Fishing Chimes 33.7 (2013): 46-49.

23. Chetia Borah B. "Grow out performance of Puntius sarana (Ham) in carp polyculture system". Journal of Inland Fisheries Society of India 44.2 (2012): 34-41.
24. Chetia Borah B., et al. "Performance of orange fin labeo, Labeo calbasu (Hamilton 1822) as a component of polyculture system". Journal of Fisheries 2.1 (2014): 86-89.

\section{Assets from publication with us}

- Prompt Acknowledgement after receiving the article

- Thorough Double blinded peer review

- Rapid Publication

- Issue of Publication Certificate

- High visibility of your Published work

Website: www.actascientific.com/

Submit Article: www.actascientific.com/submission.php

Email us: editor@actascientific.com

Contact uS: +919182824667 